\title{
Joule Thief Sebagai Boost Converter Daya LED Menggunakan Sel Volta Berbasis Air Laut
}

\author{
Anwar Mujadin $^{1}$, Suci Rahmatia $^{2}$ \\ ${ }^{1,2}$ Teknik Elektro, Fakultas Sains dan Teknologi, Komplek Masjid Agung Al Azhar, Kebayoran Baru, \\ Jakarta Selatan, Kode Pos 12110
}

Penulis untuk Korespondensi/E-mail: amujadin@uai.ac.id

\begin{abstract}
Abstrak - Joule-Thief adalah salah satu rangkaian listrik untuk konservasi energi dengan menggunakan teknis medan elektromagnetik arus transien pada sebuah coil. Sirkuit ini dioperasikan menggunakan sebuah MOSFET sebagai saklar untuk meregenerasi tegangan dan arus listrik dalam satuan waktu kemudian disalurkan pada beban light emitting diode (LED). Dari hasil eksperimental, sel volta berbasis air laut dengan tegangan jepit $0.8 \mathrm{~V}$ mampu mengaktifkan lampu LED dengan konfigurasi rangkaian serial. Hasilnya menunjukkan bahwa power transfer maksimum dari sirkuit Joule-thief sangat efektif sebagai pemasok daya beban 60 LED.
\end{abstract}

Kata Kunci - Joule Thief, Boost Converter Daya LED, Sel Volta Berbasis Air Laut

Abstract - Joule-Thief is one of the electric circuits for conservation energy by using electromagnetic field trancient current in a coil. This circuit is operated using a MOSFET as a switch to regenerating the voltage and current flowing along the coil. The electric current accumulates in the coil then in unity of time will be supplied to the light emitting diode (LED) load. From experimental results, water sea voltaic cells based with $0.8 \mathrm{~V}$ clamp voltage are able to activate LED lights in serial circuit configurations. The results shown that power transfer joule-thief circuit is very effective capable of supplying LED up to 60 LEDs.

Keywords - Joule Thief, Boost Converter Power LED, Sea-Based Voltaic Cells

\section{PENDAHULUAN}

S eiring dengan kemajuan teknologi saat ini, divais listrik pada awalnya membutuhkan energi yang besar, secara bertahap mulai diganti dengan divais hemat listri dan lebih ramah lingkungan. Upaya untuk konservasi (penghematan) listrik kemungkinan besar akan terus berkembang. Ketersediaan energi listrik yang diberikan tidak seimbang dengan kebutuhan seiring dengan pertumbuhan gaya hidup terutama di kota besar seperti Jakarta.

Salah satu konsep teknis konservasi energi melalui pengembangan komponen listrik yang menerapkan medan elektromagnetik dengan menerapkan electro mechanics force (EMF) secara komprehensif melalui konsep induksi magnetik. Salah satu aplikasi konsep diatas adalah rangkaian yang disebut Joule-thief.
Sirkuit Joule-thief dikenal sebagai rangkaian transistor pemblokiran sederhana yang bekerja sebagai pencuri energi yang bisa menghasilkan energi listrik besar dengan sumber energi sangat kecil. Rangkaian Joule-thief memiliki efisiensi tinggi, akselerasi handal dan respon dinamis yang sangat cepat [1].

Akibat perkembangan teknologi LED yang sangat pesat 5 tahun terakhir ini, semua lampu konvensional telah digantikan dengan LED. Lampu LED memiliki daya jauh lebih kecil namun memiliki fluk cahaya yang sangat kuat dibandingan teknologi konvensional seperti lampu pijar (elemen) maupun lampu neon (tungsten lamp; TL). Rangkaian Joule-thief menjadi bagian terpenting dalam penunjang lampu penerangan berbasis LED ini. 
Tulisan ini akan membahas mengenai teknis pengendalian lampu penerangan berbasis LED yang dikendalikan oleh rangkaian listrik Joulethief dimana sumber catu daya rangkaiannya menggunakan sel Volta berbasis air laut.

\section{TINJAUAN PUSTAKA}

\section{Boost Converter}

Boost-converter adalah konverter penaik tegangan DC ke level yang lebih tinggi. Sirkuit ini merupakan bentuk catu daya yang diperlukan ketika tegangan yang dibutuhkan oleh suatu divais elektronik lebih tinggi dari tegangan catu yang tersedia.

Pada Gambar 1 diperlihatkan prinsip kerja rangkaian boost converter pada posisi a) on state dan b) off state

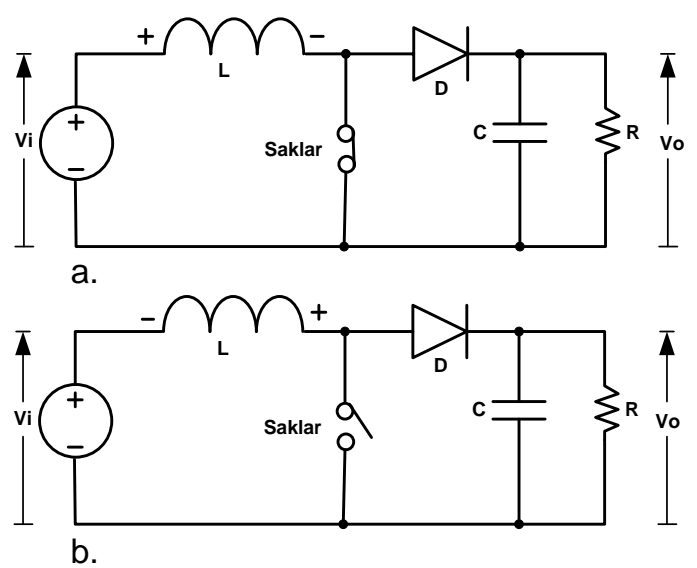

Gambar 1. Rangkaian boost converter pada a) On state b) off state

Boost converter mempunyai dua mode fungsi tergantung pada posisi saklar (umunya menggunakan MOSFET maupun transistor) dimana saklar ini bekerja buka-tutup pada frekuensi tinggi. Dari Gambar 1 (a) bila saklar tertutup, arus mengalir melewati induktor searah jarum jam dan induktor menyimpan sejumlah energi dengan meregenerasi medan magnet di sebelah sisi kiri polaritas positif induktor. Waktu saklar tertutup katakanlah $\mathrm{T}_{\text {on }}$. Berikutnya dari Gambar 1 (b) bila saklar terbuka, medan magnet tadi polaritas akan berubah (sisi kiri berubah negatif sekarang) dan medan magnet akan dihilangkan kebentuk arus listrik kemudian disalurkan ke beban. Dengan demikian hasilnya seolah-olah ada dua buah sumber secara series akan disalurkan ke beban melewati dioda $\mathrm{D}$ kapasitor $\mathrm{C}$ dan beban R. Waktu saklar terbuka katakanlah $\mathrm{T}_{\text {off }}$.

Total waktu periode (T) diformulasikan sebagai:

$$
\mathrm{T}=\mathrm{T}_{\mathrm{on}}+\mathrm{T}_{\mathrm{off}}
$$

frekuensi osilasi buka-tutup saklar dinyatakan dengan:

$$
f=\frac{1}{T}=\frac{1}{\text { Ton }+ \text { Toff }}
$$

Pada Gambar 2 diperlihatkan rangkaian boost converter secara umum [2].

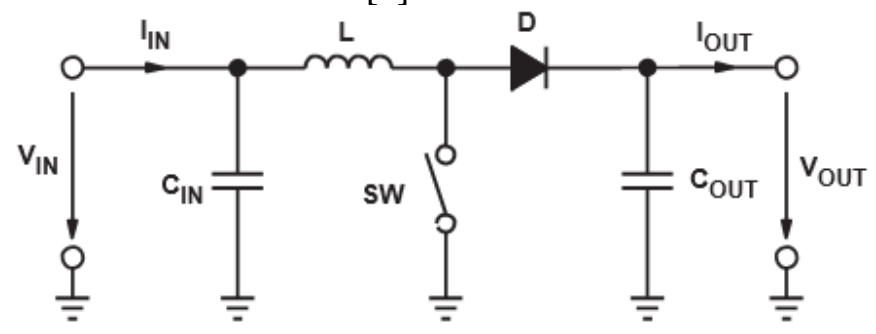

Gambar 2. Rangkaian boost converter secara umum

[2].

Empat parameter yang dibutuhkan untuk menghitung daya antara lain:

a. Input voltage range: $\mathrm{V}_{\mathrm{IN}(\min )}$ dan $\mathrm{V}_{\mathrm{IN}(\max )}$

b. Nominal Output Voltage: $V_{\text {OUT }}$

c. Maximum Output Current: $\mathrm{I}_{\mathrm{OUT}(\max )}$

d. Integrated circuit (IC) untuk membangun boost converter.

Menghitung duty cycle diformulasikan sebagai [2]:

$$
\mathrm{D}=1-\frac{\mathrm{V}_{\mathrm{IN}(\mathrm{min})} \times \eta}{\mathrm{V}_{\text {OUT }}}
$$

dimana :

$\mathrm{V}_{\mathrm{IN}(\min )}=$ Tegangan masukan minimal

$\mathrm{V}_{\text {OUT }}=$ Tegangan keluaran yang diinginkan

$\eta \quad=$ efficiency dari converter

Mencari arus riak (ripple current pada induktor)

Diformulasikan sebagai [2][3]:

$$
\Delta \mathrm{I}_{\mathrm{L}}=\frac{\mathrm{V}_{\mathrm{IN}(\min )} \times \mathrm{D}}{\mathrm{f}_{\mathrm{S}} \times \mathrm{L}}
$$

dimana:

$\mathrm{V}_{\mathrm{IN}(\min )}=$ Tegangan minimum masukan 
$\mathrm{D}=$ duty cycle

$\mathrm{f}_{\mathrm{S}}=$ frekuensi minimum switching converter

$\mathrm{L}=$ Nilai induktor

Mencari arus keluaran maksimum diformulasikan sebagai [2][3]:

$$
\mathrm{I}_{\text {MAXOUT }}=\left(\mathrm{I}_{\mathrm{LIM}(\min )}-\frac{\Delta \mathrm{I}_{\mathrm{L}}}{2}\right) \times(1-\mathrm{D})
$$

dimana:

$\mathrm{I}_{\mathrm{LIM}(\min )}=$ nilai minimum arus

$\Delta \mathrm{I}_{\mathrm{L}}=$ arus riak (ripple current) pada induktor

$\mathrm{D}=$ duty cycle

Mencari maksimum arus saklar diformulasikan sebagai [2]:

$$
\mathrm{I}_{\mathrm{SW} \text { (max) }}=\frac{\Delta \mathrm{I}_{\mathrm{L}}}{2}+\frac{\mathrm{I}_{\mathrm{OUT}(\max )}}{1-\mathrm{D}}
$$

dimana:

$\Delta \mathrm{I}_{\mathrm{L}}=$ arus riak(ripple current) pada inductor $\mathrm{I}_{\mathrm{OUT}(\max )}=$ arus maksimum keluaran

$\mathrm{D}=$ duty cycle

Mencari nilai estimasi induktor diformulasikan sebagai [2][3]:

$$
L=\frac{V_{\text {IN }} \times\left(V_{\text {OUT }}-V_{\text {IN }}\right)}{\Delta \mathrm{I}_{\mathrm{L}} \times \mathrm{f}_{\mathrm{S}} \times \mathrm{V}_{\text {OUT }}}
$$

dimana:

$\mathrm{V}_{\mathrm{IN}}=$ tegangan masukan spesifik

$\mathrm{V}_{\text {OUT }}=$ tegangan keluaran yang diinginkan

$\mathrm{fS}=$ frekuensi minimum switching converter

$\Delta \mathrm{I}_{\mathrm{L}}=\operatorname{arus} \operatorname{riak}($ ripple current) pada inductor

Mencari arus riak (ripple current) pada inductor dengan batasan riak antar 20\%-40\% didormulasikan sebagai:

$$
\Delta \mathrm{I}_{\mathrm{L}}=(0.2 \text { to } 0.4) \times \mathrm{I}_{\mathrm{OUT}(\max )} \times \frac{\mathrm{V}_{\mathrm{OUT}}}{\mathrm{V}_{\mathrm{IN}}}
$$

Pemilihan komponen kapasitor diformulasikan sebagai [2]:

$$
\mathrm{C}_{\text {OUT(min) }}=\frac{\mathrm{I}_{\text {OUT(max) }} \times \mathrm{D}}{\mathrm{f}_{\mathrm{S}} \times \Delta \mathrm{V}_{\text {OUT }}}
$$

$\mathrm{C}_{\text {OUT(min) }}=$ minimumum kapasitansi keluaran $\mathrm{I}_{\mathrm{OUT}(\max )}=$ maximum arus keluaran .
$\mathrm{D}=$ duty cycle

$\mathrm{f}_{\mathrm{S}}=$ frekuensi minimum switching converter

$\Delta \mathrm{V}_{\text {OUT }}=$ tegangan keluaran yang diinginkan

Menentukan equivalent series resistance (ESR) dari kapasitor yang digunakan, sehingga ada tambahan ripple tegangan keluaran. Ripple tegangan keluaran akibat kapasitor yang memiliki ESR diformulasikan sebagai [2][3]:

$$
\Delta \mathrm{V}_{\mathrm{OUT}(\mathrm{ESR})}=\mathrm{ESR} \times\left(\frac{\mathrm{I}_{\mathrm{OUT}(\max )}}{1-\mathrm{D}}+\frac{\Delta \mathrm{l}_{\mathrm{L}}}{2}\right)
$$

dimana :

$\left.\Delta \mathrm{V}_{\text {OUT(ESR }}\right)=$ Penambahan tegangan riak akibat kapasitor yang memiliki ESR

ESR = equivalent series resistance

$\mathrm{I}_{\mathrm{OUT}(\max ) \quad=\text { maximum arus keluaran }}$

$\mathrm{D}=$ duty cycle

$\Delta \mathrm{I}_{\mathrm{L}} \quad=$ arus riak(ripple current) pada inductor

\section{IMPLEMENTASI HARDWARE}

\section{Blok Diagram}

Pada Gambar 4 diperlihatkan blok diagram dari boost converter.

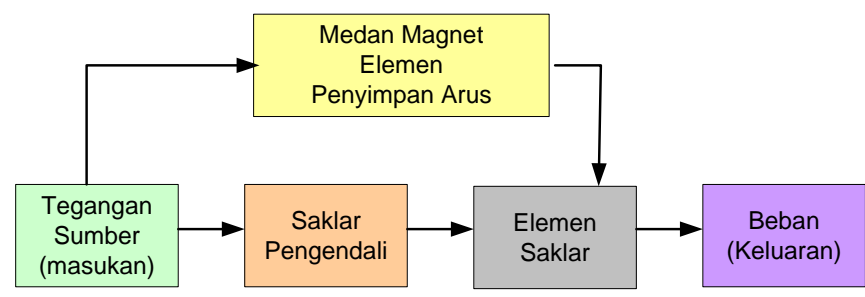

Gambar 3. Diagram blok rangkaian boost converter

Pada Gambar 4 diperlihatkan siruit dari boost convereter hasil penelitian.

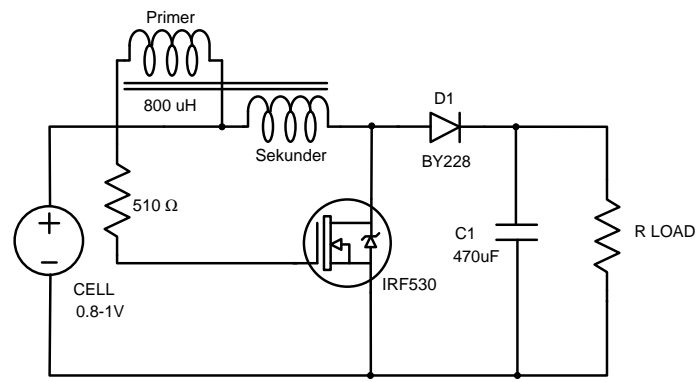

Gambar 4. Sircuit dari boost convereter hasil penelitian

Pada Gambar 5 diperlihatkan percobaan boost converter pada PCB bolong dengan baterai $1.5 \mathrm{~V}$ dan $11 \mathrm{LED}$. 


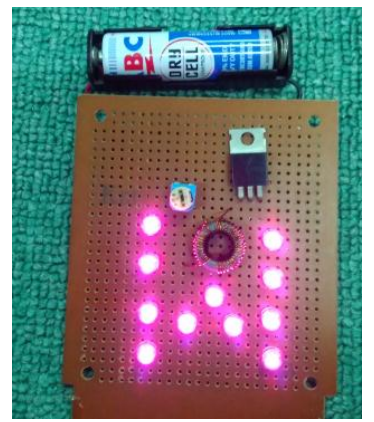

Gambar 5. Percobaan penguat konverter LED lampu penerangan

Pada Gambar 6 diperlihatkan percobaan boost converter menggunakan sumber sel baterai air laut $1.1 \mathrm{~V}-0.8 \mathrm{~V}$.

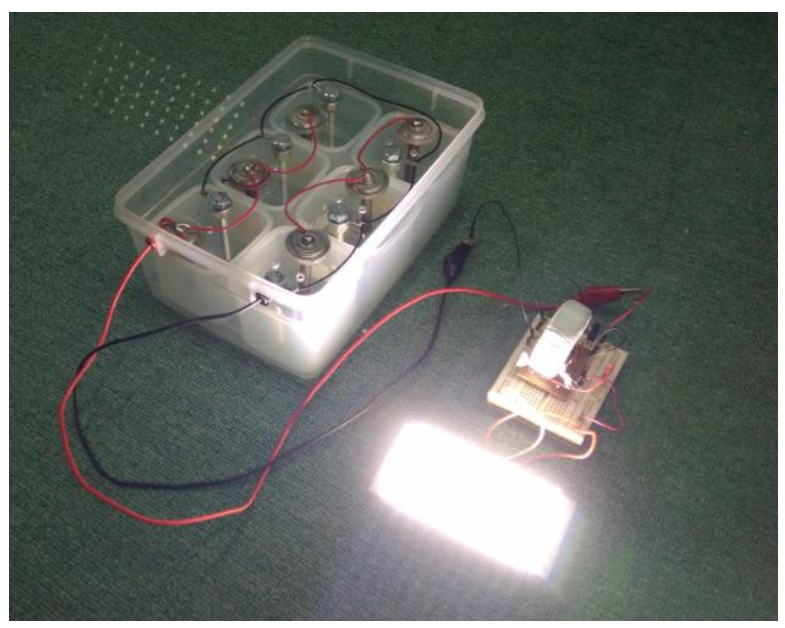

Gambar 6. Percobaan boost converter menggunakan sumber cellbaterai air laut $1.1 \mathrm{~V}-0.8 \mathrm{~V}$.

sel volta air laut dibuat dengan ukuran masingmasing berturut-turut panjang, lebar da tinggi $50 \mathrm{~mm}, 50 \mathrm{~mm}$ dan $70 \mathrm{~mm}$. Sel volta air laut menggunakan elektroda $\mathrm{Zn}^{2+}$ (seng) dan $\mathrm{Cu}^{2+}$ (tembaga). Elektroda $\mathrm{Zn}^{2+}$ (seng) dapat diambil dari bekas kaleng biskuit dan elektroda $\mathrm{Cu}^{2+}$ (tembaga) dari bahan PCB. Sel volta disusun paralel. Sel volta diujikan pada prototipe boost converter dengan jumlah lilitan primer dan sekunder $=30: 50$, LED array $12 \mathrm{~V}$ (60 buah) berukuran panjang $150 \mathrm{~mm}$ x $60 \mathrm{~mm}$. Kemudian diamati lama waktu kerja dari sel volta air laut dengan lux meter pada jarak 2 meter.

Pada Tabel 1 diperlihatkan besaran tegangan sel volta air laut terhadap waktu dan kecerahan LED.
Tabel 1. Besaran tegangan sel volta air laut terhadap waktu dan kecerahan LED (menggunakan lux meter)

\begin{tabular}{|c|c|c|c|c|}
\hline \multicolumn{2}{|c|}{ Tegangan Masukan } & \multirow{2}{*}{ Frekuensi } & Tegangan Keluaran & \multirow{2}{*}{ Kecerahan } \\
Menit & (Volt) & (K Hz) & (Volt) & (lux) \\
\hline 0 & 1.12 & 54.4 & 7.10 & 255 \\
\hline 1 & 1.00 & 53.4 & 6.78 & 250 \\
\hline 2 & 0.95 & 52.3 & 6.50 & 241 \\
\hline 3 & 0.90 & 51.6 & 6.41 & 235 \\
\hline 4 & 0.86 & 50.9 & 6.10 & 219 \\
\hline 5 & 0.80 & 50.3 & 5.90 & 200 \\
\hline 10 & 0.60 & 20.3 & 3.45 & 100 \\
\hline 15 & 0.50 & 7.4 & 2.55 & 50 \\
\hline
\end{tabular}

Dari Tabel 1 terlihat sel volta pada menit pertama menghasilkan tegangan jepit sebesar $1.12 \mathrm{~V}$ dengan 255 lux. Kemudian pada menit kelima tegangan jepit sel volta turun menjadi $0.8 \mathrm{~V}$ dan kecerahan menjadi 200 lux. Kecerahan LED (lux) berbanding lurus dengan frekuensi kerja dari boost converter. Tegangan jepit sel volta menurun menyebabkan frekuensi kerja menurun dan kecerahan LED (lux) ikut menurun. Kecerahan LED pada 200 lux (tegangan jepit sel $0.8 \mathrm{~V}$ ) masih cukup untuk menerangi area $1 \mathrm{~m} \times 1 \mathrm{~m}$ pada ketinggian 2 meter. Sel Volta akan menurun drastis pada menit ke-10, penyebabnya adalah elektron pada air laut sudah mulai jenuh (kehilangan elektron). Artinya sel volta perlu diregenerasi lagi, tiap 5 menit. Regenerasi sel volta dengan teknis jembatan garam dan air laut mengalir menjadi bagian penting dari penelitian lebih lanjut.

\section{Analisa Menggunakan simulink Matlab}

Pada Gambar 7 diperlihatkan rangkaian penguat konverter menggunakan simulink Matlab.

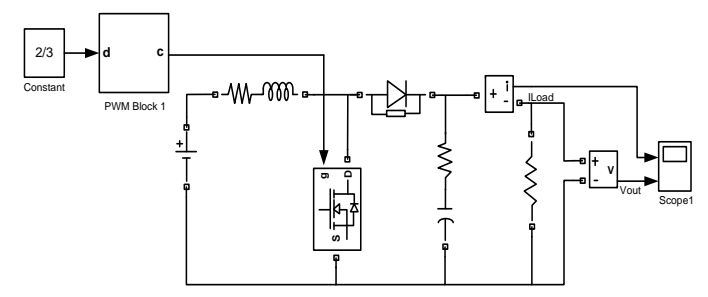

Gambar 7. Rangkaian fungsi alih boost converter menggunakan simulink Matlab.

Analisa Matlab ini dilakukan untuk melihat fungsi alih rangkaian boost conveter pengukuran arus dan tegangan keluaran dengan parameter nilai sesuai dengan Gambar 4. 
Grafik hasil simulasi Matlab diperlihatkan pada Gambar 8 (a) dan (b).

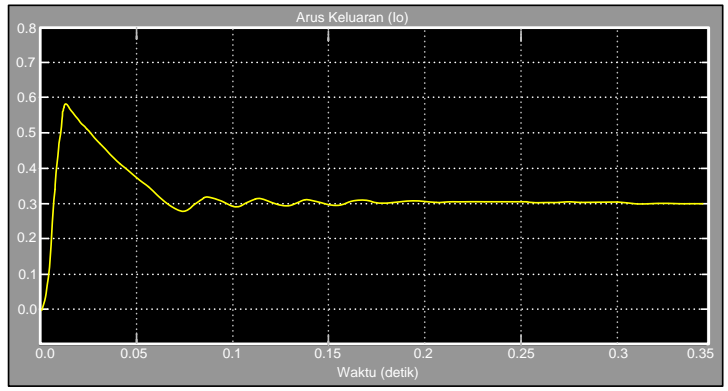

a.

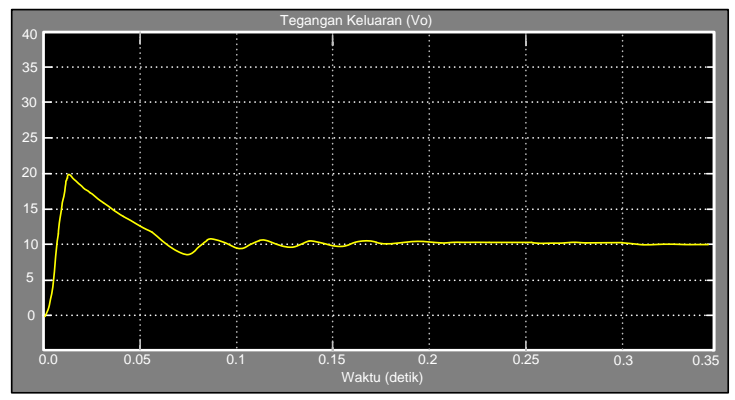

b.

Gambar 8. Hasil simulink Matlab

a. Arus keluaran (Io) sebesar 0.3A

b. tegangan keluaran (Vo) sebesar $10 \mathrm{~V}$

Frekuensi operasi pada $50 \mathrm{Khz}$. Pada Gambar 6 (a) ditunjukan dari simulasi Matlab arus keluran adalah adalah sebesar 0.3 A. Pada Gambar 6 (b) ditunjukan dari simulasi Matlab tegangan keluaran Vo sebesar $10 \mathrm{~V}$. Frekuensi $50.5 \mathrm{KHz}$ Duty cycle dipertahankan 0.6 .

\section{METODE PENELITIAN}

Pengujian dan pemilihan komponen pada papan percobaan (breadboard), kemudian dibuatkan Printed Circuit Board (PCB) menggunakan protel CAD. Solder dan perakitan komponen.

Pengujian variasi jumlah lilitan primer skunder untuk menentukan frekuensi osilasi dan tegangan keluaran boost converter. Bentuk gelombang dari sinyal keluaran di observasi menggunakan osciloscope. Intensitas cahaya LED (beban), diuji tingkat kecerahannya menggunakan luxmeter.

\section{ANALISA PENGUKURAN}

Pengujian dilakukan dengan membuat beberapa variasi jumlah lilitan pada ukuran toroid ferite dan kabel email tetap $(0.3 \mathrm{~mm})$. pada Tabel 2 diperlihatkan hasil eksperimen variasi jumlah lilitan terhadap tegangan dan frekuensi keluaran.

Tabel 2. Hasil pengukuran Variasi jumlah lilitan toroid ferite terhadap tegangan dan frekuensi keluaran

\begin{tabular}{|c|c|c|c|c|c|}
\hline \multirow{2}{*}{ No } & Primer & Sekunder & Frekuensi & \multicolumn{2}{|c|}{ Vout (Volt) } \\
\cline { 5 - 6 } & (belitan) & (belitan) & $(\mathrm{KHz})$ & No Load & Load \\
\hline 1 & 20 & 20 & 350.5 & 60 & 5.5 \\
\hline 2 & 20 & 40 & 325.2 & 30 & 3.4 \\
\hline 3 & 15 & 100 & 75.3 & 70 & 4.2 \\
\hline 4 & 30 & 50 & 51.2 & 140 & 5.9 \\
\hline
\end{tabular}

Pada percobaan No.4, kondisi tanpa beban, hasil pengukuran untuk rangkaian Joule thief menunjukkan bahwa tegangan puncak ke puncak (Vpp) adalah pada kisaran $140 \mathrm{~V}$ dengan frekuensi kisaran $51.2 \mathrm{kHz}$ pada jangkah ukur $5 \mathrm{~V} /$ div dengan atenuasi probe 10 kali. pada Saat beban LED disambungkan, terjadi drop tegangan menjadi sekitar $5.9 \mathrm{~V}$. Namun ke 60 LED mampu menyala dengan terang. Arus yang masuk ke LED terukur pada kisaran rms $275 \mathrm{~mA}$.

Pada Gambar 9. diperlihatkan screenshot osciloscope percobaan 4 dari tegangan keluaran Joule-thief 4 a) tanpa beban b) dengan beban

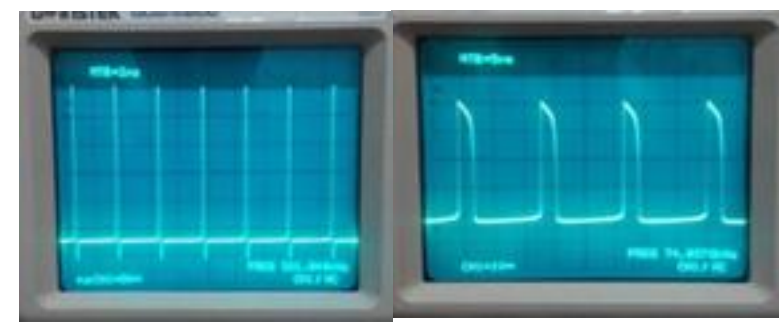

a)

b)

Gambar 9. Screenshot osciloscope dari tegangan keluaran Joule thief

a)Tanpa beban b) dengan beban

Dari Tabel 1 dapat dianalisa bahwa percobaan no 4. mnghasilkan kecerahan LED yang optimal pada frekuensi $51.2 \mathrm{KHz}$. Perbandingan jumlah lilitan antara primer dan sekunder proposonal pada 30:50 menghasilkan tegangan tinggi 140 Volt. Tegangan keluran yang tinggi menunjukan bahwa transfer daya optimal disalurkan ke beban LED. Beban LED 
pada konfigurasi seri lebih baik pada tegangan tinggi, dibandingkan beban LED pada konfigurasi parallel dengan tegangan keluran rendah.

\section{KESIMPULAN}

Rangkaian Joule thief dapat memberikan penguatan arus dan tegangan dari cell volta air laut pada tegangan jepit minimum 0.8 VDC untuk memasok rangkaian seri-parallel 60 buah beban LED dengan memanfaatkan arus transien toroidal melalui cut-breaking saklar MOSFET.

Coil (kumparan) yang diletakan pada bahan ferit toroidal (tertutup) memberikan tegangan dan arus lebih tinggi dibandingkan dengan ferit batang rod (terbuka).

Kinerja rangkaian Joule thief dapat ditingkatkan pada daya yang lebih besar, dengan cara memperbesar ukuran diameter toroid dengan saklar MOSFET.

Jumlah lilitan Primer dan sekunder harus proposonal. Dengan perbandingan lilitan primer : sekunder $=3: 5$ akan memiliki power transfer maksimum optimal untuk menyalakan LED lebih terang.

Cairan sel volta perlu di regenerasi tiap 5 menit, sehingga perlu adanya penelitian lebih lanjut mengenai sel volta air laut, terutama dalam meregenerasi elektrolit sel (air laut), dengan teknis jembatan garam dan sirkulasi.

\section{UCAPAN TERIMA KASIH}

PENELITIAN INI DIDUKUNG OLEH PRODI ELEKTRO FAKULTAS SAINS DAN TEKNOLOGI UNIVERSITAS AL AZHAR INDONESIA DARI PENGABDIAN MASYARAKAT BERBASIS RESEARCH LP2M UAI 2016

\section{DAFTAR PUSTAKA}

[1] Abdul Fathah (109EE0612). 2013. Design of a Boost Converter, Thesis, National Technologi Rourkela, india.

[2] Brigitte Hauke. 2015. Basic Calculation of a Boost Converter's Power Stage, Texas Instruments. (Diakses pada 12 Juli 2017).

[3] Zhidong Liu, Hoi Lee, 2015, Design of high-performance integrated dimmable LED driver for high-brightness solid-state lighting applications, Analog Integrated Circuits and Signal Processing International Journal, March 2015, Volume 82, Issue 3, pp 519-532 